\title{
EARLY WEANING AND OTHER POTENTIAL RISK FACTORS FOR OVERWEIGHT AMONG PRESCHOOL CHILDREN
}

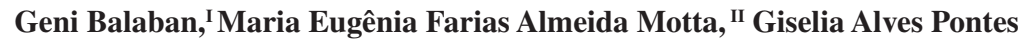 \\ Silva ${ }^{\mathrm{I}, \mathrm{III}}$
}

doi: $10.1590 / \mathrm{S1807-59322010000200010}$

Balaban G, Motta MEFA, Silva GAP. Early weaning and other potential risk factors for overweight among preschool children. Clinics. 2010;65(2):181-7.

OBJECTIVE: To investigate whether early weaning constitutes a risk factor for overweight at preschool age and to identify other factors that affect this association.

METHODS: This was a case-control study of 366 children aged 2 to 6 years (176 boys and 190 girls) from three cities. The case group comprised overweight children, as defined by body mass index (BMI) for age greater than or equal to the $85^{\text {th }}$ percentile. The main exposure analyzed was early weaning (exclusive or predominant breastfeeding for less than four months).

RESULTS: Early weaning was a significant risk factor for overweight in univariate analysis $(\mathrm{OR}=1.69 ; 95 \%$ CI: $1.10-2.60 ; \mathrm{p}=$ 0.02 ), but not in multivariate analysis ( $\mathrm{OR}=1.42 ; 95 \% \mathrm{CI}$ : 0.86-2.34; $\mathrm{p}=0.17$ ). Maternal overweight, birth weight $\geq 3,500 \mathrm{~g}$ and sedentarism were the main risk factors for overweight in multivariate analysis.

DISCUSSION: In our study, the protective effect of breastfeeding against overweight was only shown in univariate analysis; it did not persist after controlling for other variables. It is possible that breastfeeding has only a small protective role against overweight in comparison with other variables of greater importance.

CONCLUSION: Our results suggest that the potential protective effect of breastfeeding against overweight among preschool children is weaker than genetic and other environmental factors.

KEYWORDS: Children; Overweight; Obesity; Breastfeeding; Risk factor.

\section{INTRODUCTION}

In recent years, a significant increase in the prevalence of obesity has been observed in many countries and across different age groups, including children. ${ }^{1,2}$ The increase in the prevalence of childhood obesity is worrying because of obese children's higher risk of becoming obese adults and because of the various morbid conditions associated with obesity. $^{3}$

\footnotetext{
${ }^{\text {I }}$ Federal University of Ceará and School of Medicine of Juazeiro do Norte - Ceará/PE, Brazil

II Mother-Child Department of the Health Sciences Center, Federal University of Pernambuco - Recife/PE, Brazil

III Federal University of São Paulo/UNIFESP - São Paulo/SP, Brazil

Email: genibalaban@ hotmail.com

Tel.: 55812126.8514

Received for publication on October 13, 2009

Accepted for publication on November 26, 2009
}

Because obesity is a difficult-to-treat chronic disease that is associated with a variety of adverse consequences relating to morbidity and mortality, special emphasis should be given to preventive measures. Simple, low-cost measures without potential adverse effects are particularly attractive. Within this context, several authors have raised the hypothesis that breastfeeding might have a protective effect against obesity. ${ }^{4-14}=$

Epidemiological studies and experimental studies on animals have suggested that individuals' first nutritional experiences may affect their susceptibility to chronic diseases in adulthood, such as obesity, hypertension, cardiovascular disease and type 2 diabetes. This notion has been named "metabolic imprinting". ${ }^{15}$ This term describes a phenomenon through which an early nutritional experience during a critical and specific period of development might cause an enduring effect that continues throughout an 
individual's life, thereby predisposing him or her to certain diseases. ${ }^{15}$

Breastfeeding represents newborns' first nutritional experience and provides continuity with the nutrition provided during intrauterine development. Many bioactive factors are present in human milk, including hormones and growth factors, which affect the growth, differentiation and functional maturation of specific organs, thus affecting various aspects of development. ${ }^{16}$ Therefore, the unique composition of maternal milk might be implicated in the process of metabolic imprinting, for example, by changing the number and/or size of adipocytes or by inducing the phenomenon of metabolic differentiation.

The etiology of obesity has a multifactorial nature. A tendency for obesity to run in families can be seen such that children of obese parents have a higher risk of being obese themselves. In addition to genetic factors, parents and children usually share dietary habits and have similar physical activity levels, thus contributing towards the greater risk of obesity in certain families. ${ }^{17}$

High energy intake and low energy expenditure are among the main causal factors of obesity. ${ }^{18}$ In addition to total caloric intake, the composition of one's diet is also important: diets rich in simple carbohydrates and lipids are a risk factor for obesity. ${ }^{18}$ Therefore, in analyzing a possible protective role for breastfeeding against overweight and obesity, it becomes necessary to take into consideration other variables that could be involved in this association.

The aim of the present study was to investigate whether early weaning constitutes a risk factor for overweight at preschool age and to determine whether children's current diet, physical activity level and birth weight and their mothers' body mass index (BMI) are associated with overweight.

\section{METHODS}

A case-control study was carried out among children of both sexes aged two to six years who attended private schools in 2003 and 2004. The research project was assessed and approved by the research ethics committee.

The sample size of 144 cases and 144 controls was calculated with the aid of the Statcalc program in the EpiInfo software, version 6.0, using a confidence interval of $95 \%$, a power of $80 \%$, a ratio of $1: 1$ between the numbers of cases and controls, an expected frequency of the principal exposure in the control group (early weaning) of $40 \%$ and an odds ratio of 2.0, in accordance with data in the literature. ${ }^{10}$ Assuming the prevalence of overweight to be $11 \%,{ }^{2}$ around 1,309 children would need to be evaluated in order to identify 144 cases.
A free and informed consent form was sent to all parents or guardians responsible for the children within the desired age group. All children whose parents authorized their participation were included in the study (1,610 children). Their heights and weights were measured, and their BMIs were calculated.

The case group was formed by the children who were overweight, which was defined as BMI greater than or equal to the $85^{\text {th }}$ percentile for their age group. The curves and tables of BMI percentiles of the Centers for Disease Control and Prevention (CDC, United States), 2000 version (revised version of the NCHS 1977 tables), for individuals aged two to twenty years according to sex and age were used as the reference standard (www.cdc.org/growthcharts; accessed on Aug 12, 2002). The control group was formed by children whose BMIs were lower than the $85^{\text {th }}$ percentile. Children presenting diseases or using medications capable of interfering with their weights and/or heights were not included in the study.

Among the 1,610 preschool children assessed, 183 cases were identified. To make up the control group, 183 children were randomly drawn from among the pupils attending the same schools as the cases.

The main exposure studied was early weaning. Children were considered to present this exposure if they had received exclusive breastfeeding or predominant breastfeeding (i.e., maternal milk accompanied by water and/or tea) for a period of less than four months. Other variables were also evaluated, such as birth weight, maternal BMI, variables relating to the children's current diet and variables relating to the children's level of physical activity. Socioeconomic variables were also gathered, with the aim of characterizing the sample.

The children's current frequencies of intake of the following were analyzed: fruits and greens/vegetables (variables used as markers for a healthier diet). bread (representing the intake of dough from grain), soft drinks and biscuits (representing the intake of carbohydrates and sweets/candies) and chips/French fries (representing the intake of fatty and fried foods).

The following variables related to the children's physical activity levels were analyzed: average number of hours per day (on weekdays) of watching television, average number of hours per day (on weekdays) of playing outside and their most frequent means of locomotion (walking, car, motorcycle or bus).

The weights and heights of the children and their mothers were measured by a team of trained research assistants in accordance with standardized methods. ${ }^{19}$ Each measurement was taken twice, and the mean was used. The BMI was calculated using the formula of weight (in 
kilograms) divided by the square of the height (in meters). Data relating to breastfeeding and the other variables were gathered by the same team by means of interviews with the children's mothers. This information was stored in a database using double data entry and correction of inconsistencies.

The data were analyzed using Epi-Info version 6.0 and SPSS version 8.0 software. First, each variable was evaluated separately to determine whether it was a risk factor for overweight, with calculation of odds ratios and their 95\% confidence intervals. Following this, multivariate analysis was performed using the standard multiple regression method, in which all variables are simultaneously entered into the model. A statistical confidence level of $95 \%$ was adopted.

\section{RESULTS}

Among the 366 children studied, 176 were male (48.2\%) and 190 were female $(51.9 \%)$. There was no statistically significant association between sex and overweight (OR $=1.36 ; 95 \%$ CI: $0.88-2.10 ; \mathrm{p}=0.17)$. The mothers' mean schooling level was 12.5 years, and the fathers' was 11.6 years. Most of the families had one or more cars (67.8\%), were homeowners $(73.2 \%)$ and had health insurance for their children (51.9\%). There was no statistically significant association between overweight and any of these socioeconomic variables (Table 1).

Table 1 - Socioeconomic variables and risk of overweight among preschool children.

\begin{tabular}{|c|c|c|c|c|}
\hline \multirow[b]{2}{*}{ Variables } & \multicolumn{3}{|c|}{ Overweight } & \multirow{2}{*}{$\begin{array}{c}\text { Statistical } \\
\text { analysis } \\
\text { OR } \\
(95 \% \text { CI })\end{array}$} \\
\hline & $\begin{array}{c}\text { Yes } \\
\mathbf{n}(\%)\end{array}$ & $\begin{array}{c}\text { No } \\
\text { n (\%) }\end{array}$ & $\begin{array}{l}\text { Total } \\
\text { n }(\%)\end{array}$ & \\
\hline \multicolumn{5}{|c|}{ Homeowner } \\
\hline Yes & $132(49.3)$ & $136(50.7)$ & $268(73.2)$ & $\mathrm{OR}=0.89$ \\
\hline No & $51(52.0)$ & $47(48.0)$ & $98(26.8 \%)$ & $(0.55-1.47)$ \\
\hline \multicolumn{5}{|c|}{ Cars (one or more) } \\
\hline Yes & $130(52.4)$ & $118(47.6)$ & $248(67.8)$ & $\mathrm{OR}=1.35$ \\
\hline No & $53(44.9)$ & $65(55.1)$ & $118(32.2)$ & $(0.85-2.15)$ \\
\hline \multicolumn{5}{|c|}{ Health insurance (for the child) } \\
\hline Yes & $95(50.0)$ & $95(50.0)$ & $190(51.9)$ & $\mathrm{OR}=1.00$ \\
\hline No & $88(50.0)$ & $88(50.0)$ & $176(48.1)$ & $(0.65-1.55)$ \\
\hline
\end{tabular}

Note: $\mathrm{OR}=$ odds ratio; $95 \% \mathrm{CI}=95 \%$ confidence interval.

The percentage of the children who had received exclusive or predominant breastfeeding for less than four months was $36.2 \%(132 / 366)$. In univariate analysis, the children who had received exclusive or predominant breastfeeding for less than four months presented a greater risk of overweight than did those who had received exclusive or predominant breastfeeding for four months or more (OR $=1.69 ; 95 \%$ CI: $1.10-2.60 ; \mathrm{p}=0.02$ ).

Maternal overweight $\left(\mathrm{BMI} \geq 25 \mathrm{~kg} / \mathrm{m}^{2}\right)$, birth weight greater than or equal to $3,500 \mathrm{~g}$, fruit intake less than twice a day, greens and/or vegetable intake less than three times a week, consumption of one or more bread rolls per day, consumption of soft drinks every day and consumption of biscuits every day constituted risk factors for overweight in the univariate analysis. Furthermore, in the univariate analysis, it was observed that the children who played outside for an average of two or more hours a day on weekdays and those whose most frequent means of locomotion was walking presented lower risks of overweight.

It was also observed that the children who consumed chips/French fries every day and those who watched television for an average of five or more hours a day on weekdays presented higher risks of overweight. However, these associations were not statistically significant.

In the multivariate analysis, only maternal overweight, birth weight greater than or equal to $3,500 \mathrm{~g}$, playing outside for less than two hours a day and main means of locomotion other than walking remained as risk factors for overweight. The association between early weaning (receiving exclusive or predominant breastfeeding for less than four months) and overweight did not reach statistical significance in the multivariate analysis.

Table 2 presents the unadjusted and adjusted odds ratios with their respective $95 \%$ confidence intervals.

\section{DISCUSSION}

In the present study, the protective effect of breastfeeding against overweight was only shown in univariate analysis; it did not persist after controlling for other variables. It is possible that breastfeeding has only a small protective role against overweight in comparison to other variables of greater importance. ${ }^{11,18}$

Different definitions of both the exposure and the outcome make it difficult to compare this study with similar studies in the literature. The time that elapses between the exposure and the outcome also causes difficulty in analyzing this possible association. It may give rise to recall bias, or, in the case of longitudinal studies, it may impose high costs, long study durations and operational difficulties. Furthermore, the extended time that elapses between the exposure and the outcome may make it difficult to take all the confounding variables into consideration. . $^{720 ; 26-32}$

Dewey, ${ }^{26}$ in a review article, also reported that the protective effect of breastfeeding seemed to be small 
Table 2 - Logistic regression model of the risk factors for overweight among preschool children.

\begin{tabular}{|c|c|c|c|c|}
\hline \multirow[t]{2}{*}{ Variables } & \multicolumn{2}{|c|}{ Overweight } & \multirow{2}{*}{$\begin{array}{l}\text { Unadjusted OR } \\
\quad(95 \% \mathrm{CI})\end{array}$} & \multirow{2}{*}{$\begin{array}{l}\text { Adjusted OR } \\
\text { (95\% CI) }\end{array}$} \\
\hline & Yes & No & & \\
\hline \multicolumn{5}{|l|}{ Breastfeeding } \\
\hline$\geq 4$ months & 106 & 128 & 1.00 & 1.00 \\
\hline \multirow[t]{2}{*}{$<4$ months } & 77 & 55 & $1.69(1.10-2.60)$ & $1.42(0.86-2.34)$ \\
\hline & & & $\mathrm{p}=0.02$ & $\mathrm{p}=0.17$ \\
\hline \multicolumn{5}{|l|}{ Maternal BMI } \\
\hline$<25 \mathrm{~kg} / \mathrm{m}^{2}$ & 108 & 147 & 1.00 & 1.00 \\
\hline \multirow[t]{2}{*}{$\geq 25 \mathrm{~kg} / \mathrm{m}^{2}$} & 75 & 36 & $2.84(1.72-4.68)$ & $2.39(1.42-4.02)$ \\
\hline & & & $\mathrm{p}<0.0001$ & $\mathrm{p}=0.001$ \\
\hline \multicolumn{5}{|l|}{ Birth weight (g) } \\
\hline $3000-3499$ & 54 & 84 & 1.00 & 1.00 \\
\hline \multirow[t]{2}{*}{$\geq 3500$} & 81 & 57 & $2.21(1.37-3.58)$ & $2.00(1.17-3.42)$; \\
\hline & & & $\mathrm{p}=0.001$ & $\mathrm{p}=0.01$ \\
\hline \multirow[t]{2}{*}{$2500-2999$} & 39 & 35 & $1.73(0.98-3.07)$ & 1.68 (0.90-3.13); \\
\hline & & & $\mathrm{p}=0.06$ & $\mathrm{p}=0.10$ \\
\hline \multirow[t]{2}{*}{$1500-2499$} & 9 & 7 & $2.00(0.70-5.69)$ & 1.78 (0.54-5.80); \\
\hline & & & $\mathrm{p}=0.19$ & $\mathrm{p}=0.34$ \\
\hline \multicolumn{5}{|l|}{ Fruit intake } \\
\hline$\geq$ twice/day & 47 & 68 & 1.00 & 1.00 \\
\hline \multirow[t]{2}{*}{$<$ twice/day } & 136 & 115 & $1.71(1.09-2.68)$ & $1.49(0.89-2.49)$ \\
\hline & & & $\mathrm{p}=0.02$ & $\mathrm{p}=0.13$ \\
\hline \multicolumn{5}{|c|}{ Greens/vegetable intake } \\
\hline$\geq 3$ times/week & 81 & 109 & 1.00 & 1.00 \\
\hline \multirow[t]{2}{*}{$<3$ times/week } & 102 & 74 & $1.86(1.23-2.81)$ & $1.57(0.97-2.54)$ \\
\hline & & & $\mathrm{p}=0.004$ & $\mathrm{p}=0.06$ \\
\hline \multicolumn{5}{|c|}{ Bread consumption } \\
\hline$<1$ roll/day & 63 & 85 & 1.00 & 1.00 \\
\hline \multirow[t]{2}{*}{$\geq 1 \mathrm{roll} / \mathrm{day}$} & 120 & 98 & $1.65(1.06-2.59)$ & $1.38(0.85-2.26)$ \\
\hline & & & $\mathrm{p}=0.02$ & $\mathrm{p}=0.20$ \\
\hline \multicolumn{5}{|c|}{ Soft drink consumption } \\
\hline$<7$ times/week & 139 & 157 & 1.00 & 1.00 \\
\hline \multirow[t]{2}{*}{ Daily } & 44 & 26 & $1.91(1.08-3.40)$ & $1.69(0.92-3.11)$ \\
\hline & & & $\mathrm{p}=0.02$ & $\mathrm{p}=0.09$ \\
\hline Biscuit consum & & & & \\
\hline$<7$ times/week & 57 & 78 & 1.00 & 1.00 \\
\hline Daily & 126 & 105 & $1.64(1.04-2.59)$ & $1.32(0.81-2.17)$ \\
\hline & & & $\mathrm{p}=0.03$ & $\mathrm{p}=0.27$ \\
\hline Consumption o & & & & \\
\hline$<7$ times/week & 136 & 150 & 1.00 & 1.00 \\
\hline Daily & 47 & 33 & $1.57(0.92-2.69)$ & $1.38(0.79-2.41)$ \\
\hline & & & $\mathrm{p}=0.10$ & $\mathrm{p}=0.26$ \\
\hline Number of hou & & & & \\
\hline$<5 \mathrm{~h} /$ day & 161 & 170 & 1.00 & 1.00 \\
\hline$\geq 5 \mathrm{~h} /$ day & 22 & 13 & $1.79(0.82-3.92)$ & $1.18(0.51-2.70)$ \\
\hline & & & $\mathrm{p}=0.16$ & $\mathrm{p}=0.70$ \\
\hline Number of hou & & & & \\
\hline$\geq 2$ h/day & 60 & 100 & 1.00 & 1.00 \\
\hline$<2$ h/day & 123 & 83 & $2.47(1.62-3.78)$ & $2.43(1.52-3.88)$ \\
\hline & & & $\mathrm{p}<0.001$ & $\mathrm{p}<0.001$ \\
\hline Most frequent $\mathrm{I}$ & & & & \\
\hline Walking & 48 & 72 & 1.00 & 1.00 \\
\hline Others & 135 & 111 & $1.82(1.17-2.84)$ & $1.82(1.10-3.03)$ \\
\hline & & & $\mathrm{p}=0.008$ & $\mathrm{p}=0.02$ \\
\hline
\end{tabular}

Note: $\mathrm{OR}=$ odds ratio; $95 \% \mathrm{CI}=95 \%$ confidence interval. 
compared with the effects of other factors, particularly having overweight parents. Even so, the effect of breastfeeding could be important from a public health point of view considering the present epidemic of obesity seen in many countries.

Wadsworth et al. ${ }^{13}$ did not find a significant association between breastfeeding and the prevalence of overweight at 6 years of age in an analysis of 3,731 children in the United Kingdom. In a cross-sectional study of 9,357 German children aged 5 and 6 years, von Kries et al. ${ }^{(15)}$ found that the prevalence of obesity was $4.5 \%$ among children who had never been breastfed and $2.8 \%$ among those who had breastfed. A dose-dependent effect of the duration of breastfeeding was observed. After adjusting for potential confounding factors, breastfeeding remained a protective factor against overweight and obesity. Obesity was defined as BMI greater than the $97^{\text {th }}$ percentile, whereas overweight was defined as BMI greater than the $90^{\text {th }}$ percentile.

In the recent review by Owen et al.,$^{30}$ the authors concluded that breastfeeding has a protective effect against obesity, but that the magnitude of this effect is still poorly defined. These authors found 61 articles analyzing the possible relationship between breastfeeding and the risk of obesity and concentrated their attention on the 28 studies that reported odds ratios that supported a protective effect of breastfeeding. They observed that, in several studies, controlling for confounding variables led to a reduction of the protective effect of breastfeeding but did not eliminate it, and they emphasized the need to carry out other studies to determine the roles of the confounding factors.

In a wide-ranging meta-analysis, Harder et al. ${ }^{31}$ included 17 studies that reported odds ratios and $95 \%$ confidence intervals or sufficient data to calculate them; reported the duration of breastfeeding; and included children fed exclusively with infant formula for comparison. Based on these data, these authors reported that the duration of breastfeeding was inversely associated with the risk of overweight, independent of the definition of overweight used and the age of the participants in the studies. One month of breastfeeding was associated with a $4 \%$ decrease in the risk of obesity.

Evaluation of food intake is a complex task, which may at least partially explain the divergences in the literature. Several methods have been used for such evaluations, for example, 24-hour recall, food diaries, direct weighing of foods, home consumption of foods, the food frequency questionnaire and dietary history. Each of these has its advantages and limitations. ${ }^{33}$ Evaluation of food intake among preschool children is an even more difficult task because there is little data on this age group. Older age groups have been investigated much more thoroughly. ${ }^{34,35}$
It is possible that information given by individuals about their own energy intake is not a valid measurement. ${ }^{23}$ Moreover, there is evidence that genetic factors are capable of modulating an organism's response to variations in environmental factors such as diet and physical activity. ${ }^{36}$

In the same way as for energy intake, measurement of physical activity is also a complex task. Several methods can be used, such as calorimetry, systematic observation, movement sensors, heart rate monitors and questionnaires. ${ }^{37}$ Questionnaires present several advantages, such as low cost, practicality, lack of changes to individuals' behavior and possibility of adaptation of the questionnaire to the population in question. However, the literature is sparse regarding questionnaires for evaluating physical activity among preschool children. Even the extensive collection of questionnaires presented by Kriska et al. ${ }^{37}$ does not privilege this age group.

The mechanisms through which maternal milk may play a protective role against obesity have not yet been determined. In a review article, Singhal \& Lanigan ${ }^{38}$ grouped potential protection mechanisms into two major groups: those that were associated with behavioral factors and those related to the composition of maternal milk.

It is possible that maternal milk is involved in the phenomenon of metabolic imprinting. Waterland \& Garza $^{21}$ put forward some potential mechanisms through which the phenomenon of metabolic imprinting could occur. Among these are induction of variations in the structures of some organs, changes in the number of cells, and metabolic differentiation (changes in the expression of certain genes causing variations in the production of enzymes, hormones, hormonal receptors, transmembrane transporters, etc).

In terms of nutrients, the composition of maternal milk differs qualitatively and quantitatively from infant formulas. Moreover, several bioactive factors are present in human milk, including hormones like insulin, adrenal steroids, T3 and T4. ${ }^{22}$ Casabiell et al. ${ }^{39}$ identified the presence of leptin in human milk, which could play a regulatory role in the newborn's metabolism, given that the hormone acts to inhibit appetite and anabolic pathways and to stimulate catabolic

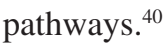

Miralles et al. ${ }^{41}$ analyzed the concentrations of leptin in samples of blood and maternal milk from 28 non-obese women and assessed the growth of their children, who were breastfed for at least 6 months, over their first years of life. These authors observed a negative correlation between the concentration of leptin in maternal milk after one month of lactation and the children's BMIs at the ages of 18 and 24 months.

Lucas et al. ${ }^{42}$ reported differences in endocrine responses with regard to the release of pancreatic and intestinal 
hormones between newborns breastfed with maternal milk and those fed with infant formula. It is also possible that the newborns who were breastfed developed more effective mechanisms for regulating their energy intake. ${ }^{43}$

Evidently, even though no significant protective effect of maternal milk against overweight and obesity has been proven, breastfeeding should continue to be strongly recommended because of its unquestionable nutritional, immunological and psychological advantages.

In summary, the results of our study suggest that the possible protective effect of breastfeeding against overweight among preschool children is of a lower magnitude than the effects of genetic factors and other environmental factors. Maternal overweight, birth weight and sedentarism are important risk factors for overweight in this age group.

\section{REFERENCES}

1. Troiano RP, Flegal KM, Kukzmarski RJ, Campbell SM, Johnson CL. Overweight prevalence and trends for children and adolescents- The National Health and Nutrition Examination Surveys, 1963 to 1991. Arch Pediatr Adolesc Med.1995;149:1085-91.

2. Mei Z, Scalon KS, Grummer-Strawn LM, Freedman DS, Yip R, Trowbridg FL. Increasing prevalence of overweight among US lowincome preschool children: The Centers for Disease Control and Prevention Pediatric Nutrition Surveillance, 1983 to 1995. Pediatrics. 1998;101:1-6.

3. Ogden CL, Troiano RP, Briefel RR, Kuczmarski RJ, Flegal KM, Johnson CL. Prevalence of overweight among preschool children in the United States, 1971 through 1994. Pediatrics. 1997;99:1-7.

4. Monteiro CA, Mondini L, Souza ALM, Popkin BM. Da desnutrição para a obesidade: a transição nutricional no Brasil. In: Monteiro CA. Velhos e novos males da saúde no Brasil- A evolução do país e de suas doenças. São Paulo: Editora Hucitec; 1995.p.247-55.

5. Serdula MK, Ivery D, Coates RJ, Freedman DS, Williamson DF, Byers T. Do obese children become obese adults?- A review of the literature. Prev Med. 1993; 22:167-77.

6. Must A. Morbidity and mortality associated with elevated body weight in children and adolescents. Am J Clin Nutr. 1996:63(3 Suppl):445S$447 \mathrm{~S}$.

7. Kramer MS. Do breast-feeding and delayed introduction of solid foods protect against subsequent obesity? J Pediatr. 1981;98:883-7.

8. Kramer MS, Barr RG, Leduc DG, Boisjoly C, McVey-White L, Pless B Determinants of weight and adiposity in the first year of life. J Pediatr. 1985;106:10-4.

9. Fomon SJ, Rogers RR, Ziegler EE, Nelson SE, Thomas LN. Indices of fatness and serum cholesterol at age eight years in relation to feeding and growth during early infancy. Pediatr Res. 1984;18:1233-8.

10. Agras WS, Kraemer HC, Berkovitz RI, Hammer LD. Influence of early feeding style on adiposity at 6 years of age. J Pediatr. 1990;116:805-9.

11. Zive MM, McKay H, Frank-Spohrer GC, Broyles SL, Nelson JA, Nader PR. Infant-feeding practices and adiposity in 4-y-old anglo-and mexican-americans. Am J Clin Nutr. 1992;55:1104-8.

12. O' Callaghan MJ, Williams GM, Andersen MJ, Bor W, Najman JM. Prediction of obesity in children at 5 years: a cohort study. J Pediatr Child Health. 1997;33:311-6.

13. Wadsworth M, Marshall S, Hardy R, Paul A. Breast feeding and obesity. Relation may be accounted for by social factors. BMJ. 1999;319:1576.
14. Tulldahl J, Pettersson K, Andersson SW, Hulthen L. Mode of infant feeding and achieved growth in adolescence: early feeding patterns in relation to growth and body composition in adolescence. Obes Res. 1999;7:431-7.

15. Von Kries R, Koletzko B, Sauerwald T, Von Mutius E, Barnert D, Grunert V, et al. Breast feeding and obesity: cross sectional study. BMJ. 1999;319:147-50.

16. Liese AD, Hirsh T, von Mutius E, Keil U, Leupold W, Weiland SK. Inverse association of overweight and breast feeding in 9 to 10-y-old children in Germany. Int J Obes Relat Metab Disord. 2001;25:1644-50.

17. Gillman MW, Rifas-Shiman SL, Camargo CA, Berkey CS, Frazier L, Rockett HRH, et al. Risk of overweight among adolescents who were breastfed as infants. JAMA. 2001; 285:2461-7.

18. Hediger ML, Overpeck MD, Kuczmarski RJ, Ruan J. Association between infant breastfeeding and overweight in young children. JAMA. 2001;285:2453-60.

19. Armstrong J, Reilly JJ, Team CHI. Breastfeeding and lowering the risk of childhood obesity. Lancet. 2002;359:2003-4.

20. Toschke AM, Vignerova J, Lhotska L, Osancova K, Koletzko B, von Kries R. Overweight and obesity in 6-to-14-year-old czech children in 1991: protective effect of breast-feeding. J Pediatr. 2002;141:764-9.

21. Waterland RA, Garza C. Potential mechanisms of metabolic imprinting that lead to chronic disease. Am J Clin Nutr. 1999;69:179-97.

22. Hamosh M. Bioactive factors in human milk. Pediatr Clin North Am. 2001;48:1-19.

23. Schonfeld-Warden N, Warden CH. Obesidade pediátrica - Uma visão global da etiologia e do tratamento. Clin Pediatr Am Norte. 1997;2:343-66.

24. Zlochevsky ERM. Obesidade na infância e adolescência. Rev Paul Ped. 1996;14:124-33.

25. World Health Organization. Physical Status: The Use and Interpretation of Anthropometry- Report of a WHO Expert Committee. Geneva, 1995.

26. Dewey K. Is breastfeeding protective against child obesity? J Hum Lact. 2003;19:9-18.

27. Kramer MS, Barr RG, Leduc DG, Boisjoly C, Pless B. Infant determinants of childhood weight and adiposity. J Pediatr. 1985;107:1047.

28. Mayer-Davis EJ, Rifas-Shimon SL, Zhou L, Hu FB, Colditz GA, Gillman MW. Breastfeeding amd risk for childhood odesity - Does maternal diabetes or obesity status matter? Diabetes Care. 2006;29:2231-7. 
29. Siqueira RS, Monteiro CA. Breastfeeding and obesity in school-age children from families of high socioeconomic status. Rev Saúde Pública. 2007;41:1-7

30. Owen CG, Martin RM, Whincup PH, Smith GD, Cook DG. Effect of infant feeding on the risk of obesity across the life course: a quantitative review of published evidence. Pediatrics. 2005;115:1367-77.

31. Harder T, Bergman R, Kallischnigg G, Plagemann a Duration of breastfeeding and risk of overweight: a meta-analysis. Am J Epidemiol. 2005;162:397-403.

32. Palma A. Overweight, a new reality on the nutritional status of preschool children in Natal (RN): epidemic or moral panic?. Rev Assoc Med Bras. 2008;54:293.

33. Bonomo E. Como medir a ingestão alimentar? In: Oliveira et al. Obesidade e anemia carencial na adolescência. Salvador: Instituto Danone; 2000. p. 117-25.

34. Domel SB. Self-reports of diet: how children remember what they have eaten? Am J Clin Nutr. 1997;65(4 Suppl):1148S-1152S.

35. Rockett HRH \& Colditz GA . Assessing diets of children and adolescents. Am J Clin Nutr 1997; 65: 1116S-22S.

36. Pérusse L, Bouchard C. Gene diet interections in obesity. Am J Clin Nutr. 2000;72: 1285S-90S
37. Ribeiro RQC. Instrumentos de Mensuração da Atividade Física. In: Oliveira et al. Obesidade e anemia carencial na adolescência. Salvador: Instituto Danone; 2000. p. 127-32.

38. Pereira MA, FitzerGerald SJ, Gregg EW, Joswiak ML, Ryan WJ, Suminski RR, et al. A collection of physical activity questionnaires for health-related research. Med Sci Sports Exerc. 1997;29(6 Suppl):S1-205.

39. Singhal A, Lanigan J. Breastfeeding, early growth and later obesity. Obesity Reviews. 2007; 8(suppl 1):51-4.

40. Casabiel X, Pineiro V, Tome MA, Peino R, Dieguez C, Casanueva FF. Presence of leptin in colostrum and/or breast milk from lactating mothers: a potential role in the regulation of neonatal food intake. J Clin Endocrinol Metabol. 1997:82:4270-3.

41. Hoppin AG, Kaplan LM. The leptin era: new insight into the mechanisms of body weight homeostasis. J Pediatr Gastroenterol Nutr. 1999;29:25064.

42. Miralles O, Sánchez J, Palou A, Picó C. A phisiological role of breast milk leptin in body weight control in developing infants. Obesity. 2006;14:1371-7.

43. Lucas A, Blackburn AM, Aynsley-Green A, Sarson DL, Adrian TE, Bloom SR. Breast vs bottle: endocrine responses are different with formula feeding. Lancet. 1980;14:1267-9.

44. Birch LL, Fisher JO. Development of eating behaviors among children and adolescents. Pediatrics. 1998;101:539-49. 